\title{
Matching Defined Contribution Pension Schemes in Japan
}

\author{
Noriyuki Takayama \\ Professor of Economics
}

Research Institute for Policies on Pension and Aging (RIPPA) and Hitotsubashi University

\begin{abstract}
More than 10 years have passed since Japan began offering defined contribution plans. Contrary to expectations, take-up has been weak, partly because account balances can be cashed out only after age 60. Beginning in January 2012, voluntary defined contribution occupational plans began to implement a new system of matching contributions. The design is very specific to the Japanese context, with workers given the chance to match employers contributions on a tax-preferred basis rather than the opposite design found in other settings. Although it is too early to determine outcomes, experience with the take-up of defined-contribution plans in Japan and the lack of incentives for workers to participate suggest that the effects will not be strong.
\end{abstract}

The use of matching contributions has emerged in a variety of countries as an incentive to extend pension coverage (Palacios and Robalino 2009). In Japan, employer matching contributions in addition to government transfers now play a crucial role in extending social security coverage. This chapter provides a summary of the structure of the Japanese pension system (Figure 7.1) and outlines the role of matching contributions within this system.

The Japanese occupational pension system remains significantly oriented toward the provision of retirement benefits in the form of lump-sum payments from an employer at the point of retirement. About 85 percent of employers provide benefit payments in this form, making it a significant part of retirement income, especially for long-term regular employees. According to a 2011 survey conducted by Japan's National Personnel Authority, the average private sector employee with service of 20 years or more received $¥ 25$ million (about \$312,500) from his or her employer as the present value of all retirement benefits, including annuities. This amount is equivalent to 10-12 times the employee's annual benefit from social security.

In January 2012, after many years of development, voluntary defined contribution occupational plans began to implement a new system of matching contributions. The design of these arrangements is very specific to the Japanese context. In contrast to the much longer established employer-based systems in the United States described in chapter 3, where the term matching contributions refers to employer contributions, in Japan the terms refers to employee contributions to match the employer contributions that provided virtually all payments into occupational pensions until 2011. The new employee matching contributions have been afforded preferential tax treatment by excluding the contributions from income and deferring taxation in the accumulated fund balances until they are withdrawn. Many Japanese are now waiting to see the effect this new development will have in the field of pensions.

The author is very grateful for the financial support from the academic Project on Intergenerational Equity (PIE), funded by the Grant-in-Aid for Specially Promoted Research from Japan Society for the Promotion of Science (grant number 22000001). 


\section{Figure 7.1 Retirement Benefits in Japan (as at March 2011)}

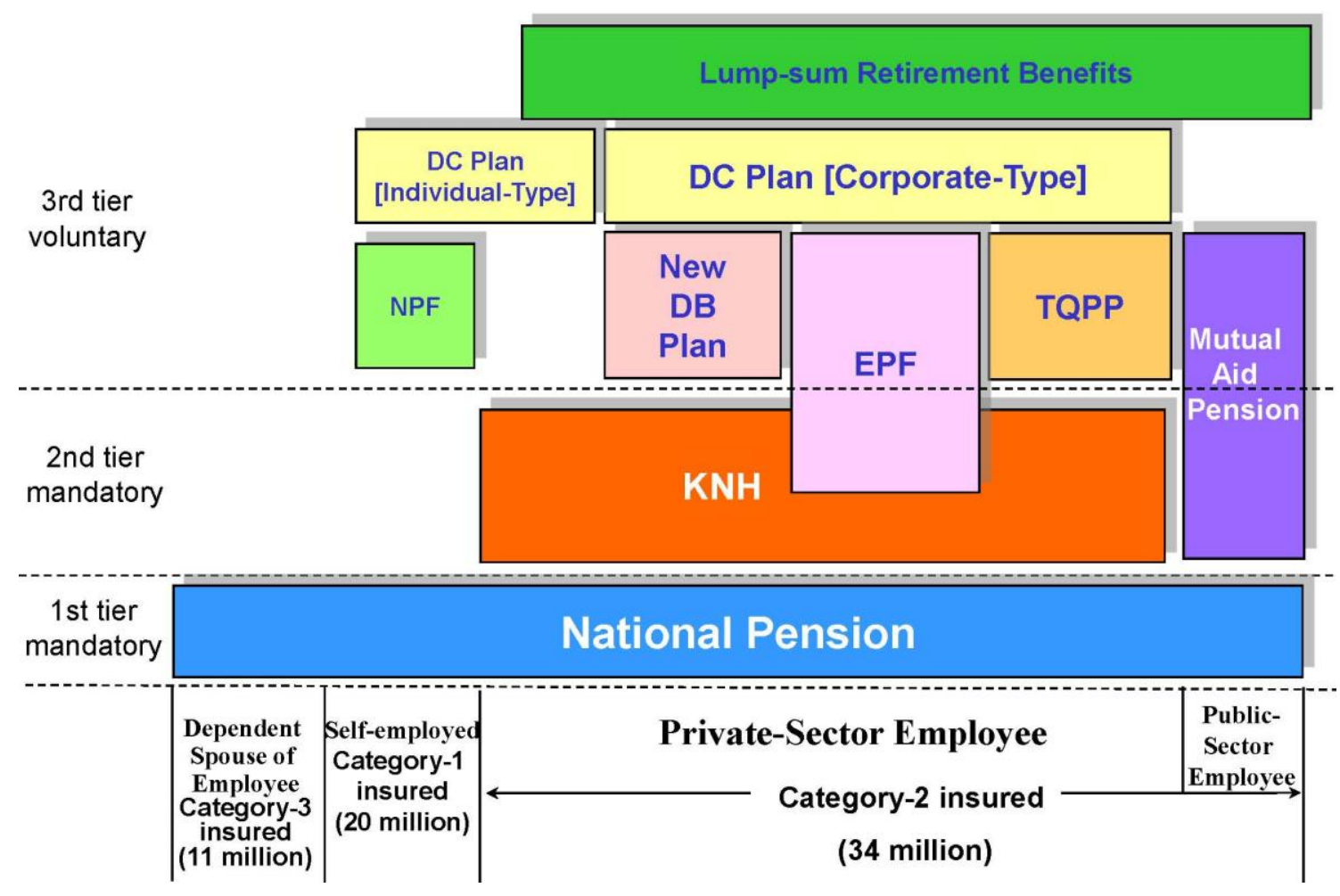

This chapter describes the matching pension schemes in Japan, examines the impact they have had, and considers potential future outcomes. The chapter is organized as follows. The first section provides a brief summary of Japan's social security system. The following section explains how matching contributions from employers and the government have extended the coverage of pensions within this system. The third section provides an overview of occupational and individual pension plans in Japan. The fourth section discusses the new employee matching contributions to defined contribution plans. The last section offers some observations on the future prospects for occupational pensions.

\section{Japan's Social Security Pension Programs}

Japan has a two-tier defined benefit system of social security pensions. The first tier provides a flat-rate basic benefit; the second tier provides an earnings-related benefit employees but also the self-employed, the unemployed, and nonemployed adults, The basic figures on social security pensions in Japan summarized in Table 7.1. Eligibility for the first tier is universal for all residents of Japan. It covers not only including full-time housewives (and househusbands). The only people eligible for earnings-related pensions are regular full-time employees who worked 30 hours or more a week. The system also provides a pension benefit to dependent spouses of regular employees.

Only people contributing to the pension scheme for 25 or more years are eligible to receive old-age benefits. The normal pensionable age is 65 . The full basic old-age pension is payable after 40 years of contributions. In 2012, the maximum monthly benefit for people with 40 years of coverage was $¥ 66,000$ (about $\$ 825$ ). The annual accrual rate for the earnings-related portion is 0.5481 percent of 
Table 7.1 Japanese Social Security at a Glance

\begin{tabular}{lrrr} 
& $\mathbf{1 9 6 5}$ & $\mathbf{1 9 8 5}$ & $\mathbf{2 0 0 8}$ \\
\hline KNH for private-sector employees & 19 & 27 & 34 \\
no. of old-age benefit recipients (million persons) & 0.2 & 3.3 & 13 \\
contribution rate (\%) & 5.5 & 12.4 & 15.35 \\
transfer from general revenue as a percentage of aggregate & 20 & 20 & - \\
benefits (\%) & & & \\
annual amount of contributions (tril. yen) & 0.3 & 7.5 & 22.7 \\
annual amount of transfer from general revenue (tril. yen) & 0.01 & 0.9 & - \\
annual amount of aggregate benefits (tril. yen) & 0.04 & 6.5 & 34 \\
current account surplus/deficit (tril. yen) & 0.34 & 5.3 & -13.5 \\
funded reserve (tril. yen) & 1.4 & 50.8 & 116.6 \\
\hline$\quad$ National Pension & $\mathbf{1 9 6 5}$ & $\mathbf{1 9 8 5}$ & $\mathbf{2 0 0 8}$ \\
\hline no. of category-1 contributors (million persons) & 17.2 & 17.6 & 19.4 \\
no. of old-age benefit recipients (million persons) & - & 6.8 & 24 \\
amount of contributions per month per person (1,000 yen) & 0.1 & 6.74 & 14.42 \\
annual amount of contribution (tril. yen) & 0.02 & 1.6 & 1.7 \\
annual amount of transfer from general revenue (tril. yen) & 0.01 & 0.8 & 1.9 \\
annual amount of benefits (tril. yen) & 0.01 & 2.8 & 4.3 \\
current account surplus/deficit (tril. yen) & 0.04 & 0.04 & -1.3 \\
funded reserve (tril. yen) & 0.19 & 2.6 & 7.2 \\
\hline
\end{tabular}

Source: Ministry of Labor, Health and Welfare, The 2009 Actuarial Report on Social Security Pensions, 2009. (in Japanese)

lifetime average salary. For a typical male retiree (with an average salary earned during 40 years of coverage) and a dependent spouse, the current replacement rate (including basic benefits) represents about 60 percent of lifetime average salary. This average benefit level is set to decrease to 50 percent in the near future.

The contribution rate of the principal program for private sector workers was about 16 percent of salary in 2012, with contributions divided equally between employees and employers ( 8 percent each). ${ }^{1}$ The monthly per person amount of contributions for people covered solely by the flat-rate benefit was about $¥ 15,000$ (about \$200) in 2012. The financing is basically pay-as-you-go, with partial prefunding. The government subsidizes half the total cost of the flat-rate basic benefit and covers all of the administrative expenses. ${ }^{2}$

${ }^{1}$ The contribution rate of Japan's principal pension program for private sector employees, the Kosei Nenkin Hoken $(\mathrm{KNH})$, is to be raised annually until it reaches 18.3 percent in 2017 , after which it will essentially become equivalent to a defined contribution plan with pay-as-you-go financing.

2 More detailed explanations of Japan's social security pension system can be found in Takayama (2003, 2004, 


\section{Matching Contributions for Extending Social Security Coverage}

\section{Kosei Nenkin Hoken}

The principal pension program for private sector employees in Japan is Kosei Nenkin Hoken (KNH). The initial design was based on a funded scheme that would build up reserves by not paying benefits in the early years. One of the main reasons for its establishment in 1942 was to reduce the purchasing power of the Japanese people during World War II through mandatory deduction of contributions from their salary, thereby helping reduce the rate of inflation.

Mandatory occupational retirement benefits with employer contributions were introduced in 1937. They were abolished with the inauguration of the $\mathrm{KNH}$, which mandated both employer and employee contributions. ${ }^{3}$ The employers' portion was a partial replacement for their contributions to the previous occupational retirement benefits, effectively establishing the concept of matching contributions. To encourage employees to contribute, the government also implemented a transfer from general revenue, initially set at 10 percent of promised benefits.

The hyperinflation that occurred in Japan just after World War II eliminated any funded reserve of the KNH and had very adverse effects on workers' welfare. Accordingly, in 1948, the (combined) contribution rate was reduced from 11 percent to 3 percent. In response, most employers voluntarily strengthened their occupational retirement benefits. The transfer from general revenue was increased from 10 percent to 15 percent in 1954 and to 20 percent in 1965 . These increases were undertaken to extend coverage. ${ }^{4}$

During Japan's long period of rapid economic growth in the late 1950s-1980s, the KNH contribution rate was reinstated to previous levels in a step-by-step process by raising it to 6.4 percent in 1973 and to 12.4 percent in 1986. Coverage of the system was also extended. Before 1988, the KNH was limited to places of business with five or more employees. Since then, the program covers employees at all business establishments.

Contributions from employers and the government, together with industrialization, enabled $\mathrm{KNH}$ coverage to expand from 3.5 million contributors in 1942 to 13.5 million in 1970 . By 2010, coverage had reached 34.4 million workers.

Some groups, however, still remain outside the system. Employees working less than 30 hours a week or less than two months are not yet covered by the KNH. The current ruling party (the Japan Democratic Party) is considering further extending $\mathrm{KNH}$ coverage to include employees working 20 hours or more a week.

\footnotetext{
2006).

${ }^{3}$ Before 1937, old-age security for employees in the private sector and self-employed people in Japan was provided mainly by families. Some companies voluntarily set up their own occupational retirement benefit schemes as a means of strengthening the loyalty of their employees and to pay a lump-sum benefit to employees who were terminated. Public sector workers in Japan have been receiving both pension annuities and a lump-sum retirement benefit since 1875 (see Sakamoto 2011).

${ }^{4}$ In the 1960s and 1970s, social insurance coverage worked as a major selling point for employers in recruiting employees.
} 


\section{National Pension}

In 1961, the National Pension was established to cover self-employed workers and the nonemployed, who receive a flat-rate benefit and make flat-rate contributions. To encourage people to participate in the program, the government set contributions at a very low level at the outset, increasing them in stages. It also made a matching contribution from general revenues, initially at a rate of half of each individual's contribution. $^{5}$

The 1961 changes also affected dependent spouses of regular employees, who were allowed to voluntarily participate in the National Pension; since 1986, their participation has been mandatory, albeit with special provisions. Dependent spouses of regular employees (typically full-time housewives) are automatically entitled to the flat-rate basic benefits without being required to make direct individual contributions to the National Pension. The funding for their benefits comes from KNH contributions as well as the transfer from general revenue. ${ }^{6}$

People with low incomes are eligible for contribution exemptions. However, people who do not make contributions are entitled to receive only one-third the flat-rate benefits, equivalent to the value of the transfer from general revenue. ${ }^{7}$ Under the various provisions outlined above, the number of people covered by the National Pension increased gradually, from 18.2 million in 1961 to 27.9 million in 1979.

Since 1986, regular employees in the private and public sectors have also participated in the National Pension. Their contributions remain proportional to their earnings; the flat-rate basic benefits of the KNH were harmonized with the flat-rate benefit provided to self-employed and nonemployed people. This arrangement has enabled the financing of the National Pension system to be integrated at the national level. ${ }^{8}$ The number of insured people in the National Pension rose from 63.3 million in 1986 to 70.1 million in 2007 (Ministry of Labor, Health and Welfare 2009). Current coverage of social security pensions is near 100 percent.

The development of this national social security system provides only half the story of Japan's retirement income system. Since the bursting of the "bubble economy" at the beginning of the 1990s, Japan has experienced persistent deflation. Many employers have sought to contain their labor costs by reducing the number of regular employees and replacing them with people who work less than 30 hours a week. The movement to more informal (or "atypical") employment was in part motivated by increases in the KNH contribution rate. ${ }^{9}$

Most atypical employees are not covered by the $\mathrm{KNH}$ and therefore do not have an earnings-related pension. Their enrollment in the National Pension is mandatory, but many fail to make pension contributions, a practice that will lead to a reduction in social security coverage in the future. In 2010

\footnotetext{
5 The transfer from general revenue in the National Pension was changed in 1976, because of budget restrictions. It was converted into a matching contribution at the time of benefit payments; one-third of flat-rate pension benefits had begun to be funded by then.

${ }^{6}$ This entitlement raises contentious issues (see Takayama 2009 for details).

${ }^{7}$ About 5.5 million people were exempted from paying contributions in 2010 (Ministry of Labor, Health and Welfare 2009).

${ }^{8}$ The transfer from general revenue to the KNH earnings-related benefits was abolished in 1986, and has been concentrated to match the flat-rate basic benefits of the National Pension.

9 The number of atypical employees in Japan almost doubled between 1990 and 2010, rising from 8.8 million to 17.1 million. The KNH contribution rate rose from 11.3 percent to 15.7 percent over the same period.
} 
about 5.5 million people (particularly younger people) were delinquent in making their National Pension flat-rate contributions. ${ }^{10}$

In 2009, the transfer from general revenue was increased from one-third to one- half of the flat-rate basic benefits. This change placed additional burdens on the national budget. Currently, about half the transfer to social security pensions is financed by government borrowing, one factor contributing to the government's increasing deficits.

\section{Occupational and Individual Pensions}

Historically, Japanese companies paid lump-sum retirement benefits when workers left their employment. As worker tenure was long and leaving a job before retirement relatively rare, these end of employment arrangements were effectively retirement plans. They were financed through a book-reserve system in which employers estimated the liability but did not set aside dedicated funds to pay the benefit.

In the mid-1960s, two major defined benefit plan types - the Employee Pension Fund (EPF) and the Tax Qualified Pension Plan (TQPP) — were introduced. Many companies transferred all or part of their lump-sum retirement benefits into the schemes to take advantage of their tax benefits and to smooth cash outflows. In October 2001, a Defined Contribution Plan was introduced. The following year, the New Defined Benefit Plan was introduced. Each of them differs in terms of applicable laws, regulatory bodies, plan management rules, and taxation.

Some people voluntarily purchase individual annuity products from financial institutions to provide additional sources of retirement income. Since April 1991, self-employed workers have also been able to voluntarily participate in the National Pension Fund to supplement their retirement income. The following section discusses this third tier of the pension system, summarized in Table 7.2. ${ }^{11}$

\section{Company-Sponsored Plans}

Before the 1960s, employer-sponsored retirement benefits in Japan were provided almost exclusively as lump-sum benefits at the time of retirement or separation from employment. In recent decades, defined benefit annuities have also become prevalent. The amount of the benefit is usually lower in the case of voluntary termination (resignation) than in the case of involuntary termination (mandatory retirement, preretirement death, disability, or discharge).

\section{Defined benefit plans}

The defined benefit plans introduced in the 1960s used to be the predominant employer-sponsored plans in Japan. Their benefit formulas are typically pay related or use a points system. Pay-related plans are based on either final pay or career average pay. Benefits are defined as pensionable pay multiplied by a factor determined by years of service and the reason for termination. In point plans, benefits are

\section{Table 7.2 Japanese Occupational and Individual Pensions at a Glance}

\footnotetext{
${ }^{10}$ About 40 percent of nonregular employees and self-employed people are delinquent in paying contributions, equivalent to about 8 percent of the total number of active participants in all social security pension programs in Japan.

${ }^{11}$ This section is a revised version of Urata and Takayama (2006). See also Clark and Mitchell (2002).
} 


\begin{tabular}{|c|c|c|}
\hline DB plans & 2001 & 2011 \\
\hline \multicolumn{3}{|l|}{ Lump-sum Retirement Benefits ${ }^{a}$} \\
\hline \multicolumn{3}{|l|}{$T Q P P$} \\
\hline no. of plans & 73,582 & 8,051 \\
\hline no. of members (million persons) & 9.16 & 1.26 \\
\hline amount of accumulated assets (tril. yen) & 19 & 4 \\
\hline \multicolumn{3}{|l|}{$E P F$} \\
\hline no. of plans & 1,737 & 595 \\
\hline no. of members (million persons) & 10.9 & 4.5 \\
\hline amount of accumulated assets (tril. yen) & 57 & 28 \\
\hline \multicolumn{3}{|l|}{ New DB } \\
\hline no. of plans & 316 & 10,053 \\
\hline no. of members (million persons) & 1.35 & 7.27 \\
\hline amount of accumulated assets (tril. yen) & - & 42 \\
\hline \multicolumn{3}{|l|}{$N P F$} \\
\hline no. of members ( 1,000 persons $)$ & 787 & 548 \\
\hline amount of accumulated assets (tril. yen) & 1.5 & 2.6 \\
\hline DC plans & 2002 & 2011 \\
\hline \multicolumn{3}{|l|}{ Corporate-type } \\
\hline no. of plans & 361 & 3,705 \\
\hline no. of members (million persons) & 0.33 & 3.71 \\
\hline amount of accumulated assets (tril. yen) & - & 5.5 \\
\hline \multicolumn{3}{|l|}{ Individual-type } \\
\hline no. of plans & 7,481 & 79,639 \\
\hline no. of members ( 1,000 persons $)$ & 14 & 132 \\
\hline
\end{tabular}

Source: Pension Fund Association, Statistical Figures on Occupational Pensions, 2012. (in Japanese)

a: Around 94 percent of employees have their retirement benefit scheme. In 2011, a private-sector employees with 20-year service or more received JPY25 million from his/her employer as the present value of all retirement benefits, out of which around JPY10 million was paid as lump-sum, on average

equal to the number of accumulated points multiplied by a unit value. Points accrue annually based on the employee's salary grade or job position, age, years of service, or a combination of these factors. Unit value is increased at the employer's discretion or through union negotiation.

In 2002, cash balance plans were introduced in Japan. These plans are technically defined benefit plans, but they resemble defined contribution plans, because they derive benefits from the value of an account balance in relation to a predetermined annuity conversion factor.

Defined benefit plans can be funded through various methods in Japan. The selection of the funding 
approach can be independent of the plan design. There are five fund types:

- Retirement allowance plans (RAPs)

- EPF plans

- TQPPs

- Fund-type defined benefit plans

- Agreement-type defined benefit plans

\section{Retirement Allowance Plans}

A Retirement Allowance Plan (RAP) is an unfunded plan in which the employer's liability is recognized via a book (accounting) reserve. RAP book reserves were tax deductible until March 2002.

The fund reserve is usually not segregated, and security of accrued benefits depends on the financial soundness of the employer. Because benefits are not funded, companies usually administer such plans themselves. For ease of administration, benefit payments are usually made in lump-sum form only. RAPs provide employers with more flexibility to change than do other plan types. ${ }^{12}$

\section{Employee Pension Funds}

The framework for EPFs was introduced in October 1966. An EPF is a separate independent legal entity established by a single employer or jointly by several employers with approval by the Ministry of Health, Labor, and Welfare. It is an externally funded plan whose principal purpose must be the payment of old-age pension benefits to participants.

EPFs are integrated with the social security system. Every EPF contracts out a part of the earnings-related old-age pension under the $\mathrm{KNH}$ and provides an additional pension from the fund on top of that portion. In return for paying the earnings-related old-age pension on behalf of the government, an EPF receives a contribution rebate. The entire system under an EPF is called the Daiko system."

For the part of the benefit that is contracted out, the EPF must provide a benefit that is greater than the benefit that would have been received under the social security system (what is known as a "plus alpha benefit") and an additional benefit on top of this contracted-out benefit. ${ }^{13}$ The distribution of benefits must be nondiscriminatory. The contracted-out benefits and the plus alpha benefits are called the "basic part"; additional benefits are known as the "additional part."

Eligibility for receiving benefits for the basic part is one month of participation in an EPF. Benefits must be paid in the form of a life annuity. If a participant terminates employment within 15 years of service, the assets equal to the present value of the accrued benefits are transferred to the Pension Fund

\footnotetext{
12 According to a 2008 survey conducted by the Ministry of Labor, Health and Walfare, 64 percent of employers who paid lump-sum retirement benefits utilized RAPs.

${ }^{13}$ The plus alpha benefits must be at least 10 percent greater than the contracted-out portion.
} 
Association, which takes over the responsibility of paying benefits. ${ }^{14}$ For the "additional part" benefits, the maximum allowable eligibility requirements are 20 years of service for an annuity and 3 years of service for a lump-sum withdrawal. Annuity payments must begin no later than age 65 . More than half of accrued benefits for the additional portion and the plus alpha portion must be paid as a life annuity, with the maximum guarantee period of 20 years or the maximum guarantee age of 85 . Beneficiaries can opt to receive a lump sum instead of a life annuity, but the amount of the lump sum must be less than the present value of the life annuity calculated using the statutory minimum assumed interest rate. An EPF may provide disability benefits and survivor benefits.

Employers usually pay all contributions for plus alpha and additional benefits, although employee contributions are allowed. Employer contributions to an EPF are tax deductible and are not treated as taxable income to employees. Employee contributions can be fully deducted in calculating income tax. This tax treatment distinguishes the EPF taxation from TQPPs and New Defined Benefit Plans (describe below).

Investment earnings are tax deferred. Plan assets are generally not subject to an annual special corporation tax. However, plan assets that exceed 2.84 times the contracted-out benefits are subject to a special corporate tax. Lump-sum benefits paid to beneficiaries are taxed as retirement benefits (with a service-year-related deduction), for which the tax rate is lower than for earned income. Annuity benefits are subject to a special income deduction. Survivor benefits are tax free.

Mainly because of an unfavorable investment environment, many EPFs were dissolved during the past 15 years. The Ministry of Health, Labor, and Welfare must approve EPF dissolutions before EPFs settle their assets. Stringent prerequisites must be met before approval of dissolution is granted. If EPF assets are less than the value of the corresponding contracted-out benefits, a one-time contribution to cover the shortfall is required. Once an EPF is dissolved, assets with a value corresponding to contracted-out benefits are transferred to the Pension Fund Association, which takes over responsibility for paying contracted-out benefits. Any residual assets are allocated to participants and beneficiaries according to the rule of distribution stipulated by the EPF plan documents. Participants can choose to receive these benefits as a lump sum or to transfer them to the Pension Fund Association for future annuity payments.

Employers must compensate for the investment loss derived from the contracted-out portion and recognize the projected value of benefits for the contracted-out portion on their books. The contracted-out portion used to bring in extra profits to EPFs. Once the investment environment turned adverse, however, the contracted-out portion began to hurt EPF operation.

Many employers and trade unions lobbied for legislation that allows EPFs to return the contracted-out portion to the original social security regime. Since April 2002, it has been possible for EPFs to do so (daiko henjo). Once EPFs return the contracted-out portion, additional benefits and plus alpha benefits are transformed into New Defined Benefit Plans.

14 The Pension Fund Association was founded in 1967 as a federation of EPFs. The main objective of the Association is to provide pension benefits to those who seceded from EPFs after a short period and to pay contracted-out benefits to those whose EPFs are dissolved, as well. 
The number of EPFs reached a peak of 1,225 in 1997. Thereafter it began to decrease sharply, falling to 568 in 2011, covering 4.4 million employees. The daiko henjo amounted to 813 by 2009 .

\section{Tax-Qualified Pension Plans}

The TQPP, introduced in 1962, used to be one of the two major occupational pension schemes in Japan. It was an externally funded, tax-favored retirement benefit plan. Because there was no minimum participation requirement, TQPPs were popular among small to medium-size companies.

TQPPs had no benefit eligibility requirements (unlike EPFs and New Defined Benefit Plans), and benefits were paid upon termination of employment (in contrast, EPFs and New Defined Benefit Plans pay benefits when participants attain a prescribed age). The form of payment had to be either a fixed annuity of five years or longer or a life annuity (most TQPPs provided only fixed annuities). Beneficiaries could opt to receive a lump sum instead of annuities, but the amount of the lump sum was less than the present value of annuities calculated with the interest rate stipulated in the plan document. TQPPs could provide survivor benefits but not disability benefits.

Policy makers eventually recognized that TQPP regulations were inadequate to protect employees' rights to receive benefits. As a result, employers were required to convert TQPPs to other types of pension plans by March 2012. Some TQPP sponsors switched to other types of pension plans; most simply terminated their TQPPs, leaving employees without any retirement plan.

\section{New Defined Benefit Plans}

Two kinds of New Defined Benefit Plans - the fund type and the agreement type - were introduced in April 2002, in order to unify regulations and enhance protection of vested benefits for participants.

Fund-type plans are similar to EPFs, with separate governing boards but without contracted-out benefits. The legal minimum number of participants for the fund type is 300. Existing EPFs can switch to the plans by surrendering contracted-out benefits to the government.

Agreement-type funds replaced TQPPs, which had problems protecting vested benefits because plan operations were not fully regulated and there were no minimum standards to ensure the annual evaluation and maintenance of full funding status. They are similar to TQPPs. They have a contract with a lead manager, but, unlike TQPPs, they are subject to minimum funding rules, fiduciary duties, and disclosures.

There is no legal minimum number of participants for an agreement-type plan. Benefits must be provided as a fixed annuity of at least five years or as a life annuity. Old-age annuity benefits must begin to be paid between the ages of 60 and 65 for normal retirement but can begin as early as age 50 for early retirees. Beneficiaries can opt for a lump-sum payment instead of annuity payments. The lump-sum value must be equal to or less than the present value of annuities for a guaranteed period. Maximum benefit eligibility requirements are 20 years of service for an annuity and 3 years of service for a lump-sum pay-out. Survivor and disability benefits are permitted.

To protect vested benefits for participants, strict funding rules apply. Employers make contributions to fund plan assets. Employees are permitted to contribute up to 50 percent of total contributions if plan documents allow them to do so. Actuarial valuation must be performed at least every five years. Each 
employer determines an assumed interest rate, based on long-term expected investment returns. However, the rate must be equal to or above the minimum assumed interest rate set by the Ministry of Health, Labor and Welfare.

The New Defined Benefit Plan law also permits cash balance-type plans. Pay credit is given to notional accounts, along with an interest credit based on the following rates:

- A fixed rate

- A government bond rate or other objectively measurable stable index (the national wage index or the cost of living index is acceptable; the equity index is not)

- A combination of a fixed rate and government bond rate

- A fixed or government bond rate with applicable minimums or maximums.

The conversion rate between annuity and lump-sum payments can be indexed regardless of the plan design structure.

In 2011, there were 610 fund-type and 11,593 agreement-type defined benefit plans in Japan, together covering 7.3 million employees.

\section{Defined contribution plans}

The number of defined contribution plan documents approved by the government has constantly increased since the plans were first introduced in Japan in October 2001. Still, as of the end of October 2011, only 4,013 plans had been approved, covering just 16,000 employers. The numbers of participants were 4.1 million in corporate-type defined contribution plans and 132,000 in individual-type defined contribution plans.

One motivation for this trend is that many companies are replacing seniority-pay systems with performance-based compensation. Traditional retirement benefit plans that favor long-term workers are inconsistent with this approach to managing human resources.

More and more companies are trying to reflect individual work performance in the design of retirement benefits. Companies are also trying to improve employees' understanding and appreciation of retirement benefits. More visible retirement plans, such as defined contribution plans and cash balance plans with individual accounts, are perceived as advancing this objective.

The Japanese labor market is also becoming more fluid and workers more mobile. Traditional retirement plan designs based on a lifetime employment model are not suitable for attracting and retaining talented people.

Mergers and acquisitions have also become prevalent since the deregulation of business reorganization rules. Harmonization of retirement benefits is required in merger and acquisition situations. The need for flexibility to accommodate these organizational changes has provided an important impetus for the emergence of defined contribution plans.

There are two types of defined contribution plans in Japan: corporate-type and individual-type plans. The amount of employer contributions is fixed regardless of its profits: contribution formulas must be a fixed percentage of participants' pay or a fixed amount for every participant. Employee contributions were not originally allowed in corporate-type defined contribution plans, but they have been allowed 
since January 2012.

In individual-type defined contribution plans, employees or self-employed workers can contribute to the plan at their discretion. Employers, however, cannot make matching contributions to individual-type defined contribution plans. (In Japan, "matching contributions" in defined contribution plans refers to employee contributions that are made to match those of the employer rather than employer matching of employee contributions, as in the United Kingdom and the United States.)

Regular employees who are covered by the $\mathrm{KNH}$ are eligible for corporate-type defined contribution plans once their employer establishes such a plan. There are two separate contribution limits for corporate-type plans. If employers maintain an EPF or a New Defined Benefit Plan along with their defined contribution plan, contributions to individual accounts are limited to $¥ 25,500$ a month (about \$320). If they do not maintain such plans, the limit is $¥ 51,000$ a month (about \$640).

If employers do not sponsor a defined benefit plan or a corporate-type defined contribution plan, employees are eligible to participate in individual-type defined contribution plans. The contribution limit for these plans is $¥ 23,000$ (\$290) a month. Self-employed workers can participate in individual-type defined contribution plans, with a limit of $¥ 68,000$ a month (\$850) on their combined contributions to the plan and to the National Pension Fund. Public sector employees and full-time housewives/househusbands are not eligible for either corporate-type or individual-type defined contribution plans.

Participants select investment options from a list presented for their individual account. At least three options must be provided. Bank deposits, mutual funds (investment trusts), and insurance products are commonly presented as investment options. One of the investment options must be a principal-guaranteed product, such as a time deposit or guaranteed investment contract. Securities of the employer can be one investment option, although they are rarely offered. No real estate investment option is permitted. Participants can change their investment options every three months. Plan administrators must provide information on account balances to participants at least once a year.

Benefits are payable when participants with more than 10 years of participation reach age 60 . If participants leave the company before age 60, they must roll over the account balances to a new employer's defined contribution plan or an individual-type defined contribution plan. There are two exceptions to this rule. If an employee leaves with no more than three years of participation and becomes ineligible for any type of defined contribution plan (as would be the case for full-time housewives/househusbands or public sector employees), the vested account balance, if any, can be paid out in cash. If an account balance is $¥ 500,000$ (\$6,250) or less, a lump-sum withdrawal payment can be received regardless of the participation period. These exceptions were made to eliminate recordkeeping burdens and the maintenance of small account balances.

Participants can start receiving benefits any time between age 60 and 70, but they must begin receiving benefits by age 70 . Benefits are paid in a lump sum or in installments extending over 5-20 years. Life annuities can also be offered. After three years of service, participants are 100 percent vested in corporate-type defined contribution plans.

When a participant in an individual-type defined contribution plan changes jobs to become an employee, his or her account balance must be rolled over to the new employer's corporate-type defined 
contribution plan. If the new employer does not sponsor a corporate-type defined contribution plan, the account balance remains with the individual-type defined contribution plan.

In corporate-type defined contribution plans, employer contributions are a tax-deductible business expense and are not treated as taxable income for employees. In individual-type defined contribution plans, participants can deduct contributions from their taxable income, and investment earnings are tax deferred. Rollover is tax free. Lump-sum benefits paid to beneficiaries are favorably taxed as retirement benefits (with a service-related deduction). The contribution period is considered as the service period. Annuity benefits are also subject to a special income deduction.

\section{Employee Matching Contributions to Defined Contribution Plans}

Pension legislation was enacted in August 2011 that authorized the launch of employee matching contributions under current defined contribution plans beginning in January 2012. This new matching scheme is structured as follows (see Endo 2011 for more details):

1. Employee matching contributions for corporate-type plans are voluntary.

2. Employees' matching contributions cannot exceed their employers' contributions.

3. The combined total of the employee and employer contributions cannot exceed the upper limit for tax privileges.

4. Employers are responsible for ensuring that contributions do not exceed the limit.

5. Employee contributions are deducted by the employer from each employee's salary. They are tax deductible at the contribution stage. Investment earnings are not taxed if they remain in the plan.

6. Benefits are payable only after age 60. They represent taxable income when received, although subject to a special income deduction.

The tax privileges and gains from earlier contributions are two selling points for the new scheme, which is intended to make corporate-type defined contribution plans more attractive. Critics have noted, however, that the second and third requirements make the employee matching contribution redundant. Given that the combined tax limit is $¥ 51,000$ (about \$640) a month, the maximum combined contribution of $¥ 25,500$ (\$320) from an employer limits the employee maximum contribution to the same amount. If the employer contributes less than $¥ 25,500$, the maximum contribution from the employee must decrease accordingly. Consequently, the employee matching maximum contributions will vary depending on the employer contributions, which can result in a different level of allowable contributions among employees of different firms with the same salary.

The new scheme for matching contributions imposes additional handling costs on employers. If the employer's contribution to the defined contribution plan is proportional to the salary of each employee, then every year employers are forced to review and confirm whether their employee matching contributions fall below the approved upper limit.

Tax privileges for employee contributions have become both more complicated and less fair, it can be argued, because individual-type defined contribution plans allow monthly matching contributions of up to either $¥ 23,000$ (\$290) or $¥ 68,000$ (\$850 whereas corporate-type plans allow matching 
contributions up to $¥ 25,500$ (\$320). The wall between individual- and corporate-type plans has been virtually dismantled, but inequalities among individual employees in making contributions to defined contribution plans remain.

\section{Future Prospects for Defined Contribution Pension Plans and Matching Contributions}

More than 10 years have passed since defined contribution plans were introduced in Japan. At the time of their introduction, it was widely expected that they would expand rapidly. This did not happen. In March 2011, the aggregate amount of accumulated assets in occupational plans was only about ¥5.5 trillion ( $\$ 69$ billion) for defined contribution plans and about $¥ 80$ trillion ( $\$ 1.0$ trillion) for defined benefit plans.

Why has the growth of defined contribution plans been so slow? The major factor is the restriction of cash-out only after age 60. Most small and medium-size companies used to pay lump-sum retirement benefits to early leavers or employees reaching the mandatory retirement age from their occupational pension plans. The fact that defined contribution plans are not able to do so makes them far less attractive to workers and employers than the existing defined benefit plans, which have no such restrictions.

Another factor is the very low maximum imposed on contributions to defined contribution plans (existing defined benefit plans have no maximums). This limit has led potential service providers who might promote the arrangements to believe that defined contribution plans are not a profitable business.

A third factor is that reducing benefits of a defined benefit plan requires the consent of two-thirds of plan participants. When employers want to introduce a defined contribution plan by replacing part of their existing defined benefit plan, this requirement becomes a bottleneck, thereby discouraging them from switching.

A fourth factor is very low (or negative) returns observed in the domestic capital markets for nearly two decades. As of October 2011, about 60 percent of plan participants in Japan had incurred a loss of principal on their accumulated defined contribution assets.

The future of defined contribution plans in Japan will likely depend on whether the design limitations evolve to allow employees to take cash payments at the termination of employment before age 60 and on the potential for a significant increase in the upper limit for contributions. Japan has a long history of not providing tax incentives for personal savings. Saving for retirement is the single exception to this rule. The requirement restricting the ability to cash out before age 60 was imposed in order to provide defined contribution plan contributions with preferential tax treatment similar to that afforded employer-sponsored plans. Individual contributions to defined contribution plans are obliged to follow this rule to receive this tax privilege.

Employer contributions, however, are not necessarily regarded as personal savings but rather as retirement benefits. It is therefore inconsistent with the treatment of other employer-provided benefits to restrict the ability to cash out the benefit upon a change of employment to employer contributions in these plans.

The matching contribution provisions that now apply to defined contribution plans are very recent; 
the effect these provisions will have on growth within these plans is therefore not yet known. Concerns have already been raised regarding the potential the provisions will have to stimulate meaningful expansion of the nascent defined contribution system. The design of the new arrangement that allows employees to contribute only to the extent that the employer is willing to pay into the plan is the opposite of the approach in other countries, where the sponsor's match provides an inducement for employees to join and contribute. This reversed design does not provide strong incentives for either party, and it imposes additional restrictions and potential burdens on both.

The limited acceptance of these new plans likely will provide a strong example of the importance of context, cultural norms, and perceptions on behavior and the influence that the historical development of a pension system has on the capacity of design innovations such as matching contribution to expand participation and levels of saving. In the presence of a well-established social security system providing meaningful basic benefits to the full population and a relatively high prevalence of supplementary defined benefit arrangements (as indicated in the evidence from other countries in the Organisation for Economic Co-operation and Development presented in chapter 2), there is not likely to be strong demand for supplementary defined contribution savings.

Defined contribution plans could grow in Japan in the long run, but their short-time prospects are weak. Development of these plans crucially depends on the extent to which the schemes evolve to better fit the Japanese environment, meet the needs of participants, and become user friendly.

\section{References}

Clark, R. L., and O. S. Mitchell. 2002. "Strengthening Employment-Based Pensions in Japan,” NBER Working Paper 8891, National Bureau of Economic Research, Cambridge, MA.

Endo, T. 2011. "Pension Reform in Japan: The 2011 Law and Future Issues." Benefits \& Compensation International 41 (5): 15-22.

Ministry of Labor, Health and Welfare. 2009. The 2009 Actuarial Report on Social Security Pensions, 2009. (in Japanese)

Palacios, R., and D. A. Robalino. 2009. "Matching Defined Contributions: A Way to Increase Pension Coverage." In Closing the Coverage Gap: The Role of Social Pensions and Other Retirement Income Transfer, ed. R. Holzmann, D. A. Robalino, and N. Takayama, 187-202. Washington DC: World Bank.

Sakamoto, J. 2011. “Civil Service Pension Arrangements in Japan.” In Reforming Pensions for Civil and Military Servants, ed. N. Takayama, 113-29. Tokyo: Maruzen Publishing Co., Ltd.

Takayama, N., ed. 2003. Taste of Pie: Searching for Better Pension Provisions in Developed Countries. Tokyo: Maruzen Publishing Co., Ltd.

2004. “Changes in the Pension System.” Japan Echo 31 (5): 9-12.

. 2006. "Reforming Social Security in Japan: Is NDC the Answer?" In Pension Reform: Issues and Prospects for Non-Financial Defined Contribution (NDC) Schemes, ed. R. Holzmann and E. Palmer, 639-47. Washington, DC: World Bank. 
2009. "Pension Coverage in Japan." In Closing the Coverage Gap: The Role of Social Pensions and Other Retirement Income Transfer, ed. R. Holzmann, D. A. Robalino, and N. Takayama, 111-18. Washington, DC: World Bank.

Urata, H., and N. Takayama. 2006. "Pension Regulation in Japan: Issues and Reforms." In Labour Market Regulation and Deregulation in Asia, ed. C. Brassard and S. Acharya, 197-218. New Delhi: Academic Foundation. 